\title{
Dietary antioxidants and environmental stress
}

\author{
Frank J. Kelly \\ Lung Biology, School of Health \& Life Sciences, King's College, London, 150 Stamford Street, \\ London SE1 9NN, UK
}

\begin{abstract}
Air is one of our most important natural resources; however, it is also in the front line for receiving environmental pollution. Air quality decreased markedly following the industrial revolution, but it was not until the great London Smog in 1952 that air quality made it onto the political agenda. The introduction of the Clean Air Act in 1956 led to dramatic decreases in black smoke and $\mathrm{SO}_{2}$ concentrations over the next two decades, as domestic and industrial coal-burning activities ceased. However, as these improvements progressed, a new threat to public health was being released into the air in ever-increasing quantities. Rapid motorisation of society from the 1960s onwards has led to the increased release of atmospheric pollutants such as tiny particles (particulate matter of $<10 \mu \mathrm{m}$ in aerodynamic diameter) and oxides of $\mathrm{N}$, and the generation of the secondary pollutant $\mathrm{O}_{3}$. These primary and secondary traffic-related pollutants have all proved to be major risks factors to public health. Recently, oxidative stress has been identified as a unifying feature underlying the toxic actions of these pollutants. Fortunately, the surface of the lung is covered with a thin layer of fluid containing a range of antioxidants that appear to provide the first line of defence against oxidant pollutants. As diet is the only source of antioxidant micronutrients, a plausible link now exists between the sensitivity to air pollution and the quality of the food eaten. However, many questions remain unanswered in relation to inter-individual sensitivity to ambient air pollution, and extent to which this sensitivity is modified by airway antioxidant defences.
\end{abstract}

Antioxidants: Oxidative stress: Air pollution: Lung function: Vitamins

Air is one of the most important natural resources on which all life depends. The atmosphere is, however, also in the front line for receiving environmental pollution. Increased industrialisation of the major cities in the UK gave rise to a marked increase in air pollution. For example, smoke plumes from factories and power stations, which combined with fog to produce wintertime smogs, were characteristic of cities such as London. Indeed, during the Victorian era such smogs were an integral component of the tourist attraction of London, as typified by Monet's frequent visits to paint the charismatic London smog. About 50 years later, on 4 December 1952, this view changed dramatically when an anticyclone settled over London. As a result, the wind dropped and the smog that built up over London did not dispel as usual but lasted for $5 \mathrm{~d}$. During this time, many thousands of the population died and many more became sick. The dramatic increase in air pollution during the first week in December was subsequently agreed to be responsible for this public health disaster. Examination of the data revealed that $\mathrm{SO}_{2}$ concentrations had increased 7-fold, peaking at $2000 \mu \mathrm{g} / \mathrm{m}^{3}$ and black smoke levels had increased 3-fold to approximately $1600 \mu \mathrm{g} / \mathrm{m}^{3}$ during the smog episode. Moreover, peaks in both factors coincided with the time of the greatest number of deaths. In response to sustained public and political pressure the government of the day introduced the Clean Air Act in 1956 (UK Parliament, 1956) to reduce the emission of atmospheric pollutants. As a consequence, during the 1960s air quality in many cities in the UK went through a marked transition and deaths directly attributable to 'smog type' air pollution largely disappeared. However, as industrial and domestic use of coal was decreasing there was an increase in the number of vehicles on the roads. Furthermore, the introduction of the motorway network and improved road infrastructure led to vastly increased annual mileage averages. For example, vehicle traffic increased 7-fold between 1960 and 2000 from $50 \times 10^{9}$ vehicle $\mathrm{km}$ per year to $350 \times 10^{9}$ vehicle $\mathrm{km}$ per year. As a consequence, attention

\footnotetext{
Abbreviations: $\mathrm{FEV}_{1}$, forced expiratory volume in $1 \mathrm{~s}$; FVC, forced vital capacity; PM, particulate matter; RTLF, respiratory-tract lining fluid. Corresponding author: Professor Frank J. Kelly, fax +44 207848 3891, email frank.kelly@kcl.ac.uk
} 
Table 1. Types and sources of airborne pollutants

\begin{tabular}{ll}
\hline Pollutant & Source \\
\hline $\mathrm{NO}_{2}$ & $\begin{array}{c}\text { Combination of fossil fuels from stationary sources: heating; power generation; motor vehicles } \\
\mathrm{O}_{3} \\
\text { Strong oxidising agent formed in the air through a complex series of reactions involving sunlight } \\
\text { (UV radiation) on } \mathrm{NO}_{2} \text { and hydrocarbons } \\
\text { Particulate matter (PM) } \\
\text { mechanically produced and natural PM; fine fraction }(0 \cdot 1-2 \cdot 5 \mu \mathrm{m}), \text { small PM, may be formed from } \\
\text { gaseous reactions; ultrafine fraction }(<0 \cdot 1 \mu \mathrm{m}), \text { formed by nucleation resulting from condensation reactions }\end{array}$ \\
\hline
\end{tabular}

has shifted from the traditional sources of pollution in the energy and industrial sectors to traffic-related pollution. These new pollutants broadly fall into primary source pollutants such as oxides of $\mathrm{N}$ and particulate matter (PM) and secondary photochemical pollutants such as $\mathrm{O}_{3}$ (see Table 1). Although all these pollutants are bad for public health, the effects of PM particularly have caught the attention of researchers in the last decade. Two USA-based studies have been primarily responsible for this increased profile, as they have both provided convincing evidence that the concentration of PM in air is related to life expectancy (Dockery et al. 1993; Pope et al. 1995). Importantly, the decrease in life span is estimated to be 1-2 years, which is large when compared with other environmental risk factors related to mortality. As a consequence of this work and a number of follow-up studies (Abbey et al. 1999; Dockery, 2001; Pope et al. 2002), air pollution is attracting increasing attention from both the political and scientific communities. As a result of increased awareness of the problem, weather forecasts in newspapers and on television now warn the public when poor air quality threatens, whilst free government telephone numbers can be used to obtain more detailed information. When air quality is poor, sensitive individuals such as asthmatics are advised to avoid strenuous exercise, particularly outdoor exercise. Clearly, any form of exercise increases the breathing rate and hence the amount of (contaminated) air that is entering the lung.

Although legislation has been introduced in the UK, across Europe and in the USA to control traffic emissions, pollution still exists and its eventual resolution will require substantial change in the attitudes of many individuals and all governments. In the meantime, the impact of trafficgenerated air pollutants will probably be present for several decades. For those in the public health arena who have to deal with the problem it is clear that the current science base does not provide an adequate understanding of the impact of traffic-related pollutants on health. Considerably more work is therefore required before a firm understanding of the mechanisms underlying pollution-induced effects on human health is obtained.

\section{The effects of air pollution}

Inhalation of pollutants at concentrations encountered during typical episodes induces a range of symptoms in patients with established respiratory conditions and even in some healthy subjects (Koren et al. 1989; Devlin et al. 1991; Schelegle et al. 1991; Aris et al. 1993). For example, breathing only slightly elevated concentrations of $\mathrm{O}_{3}\left(120-240 \mu \mathrm{g} / \mathrm{m}^{3}\right)$ results in a range of respiratory symptoms in a small percentage (10-20) of the healthy population (Mudway \& Kelly, 2000). Symptoms include decreased lung function, increased airway hyper-reactivity and pulmonary inflammation. Those individuals with preexisting conditions such as asthma and chronic obstructive pulmonary disease generally experience an exacerbation of their symptoms. Similarly, $\mathrm{NO}_{2}$ arising from traffic outdoors and gas appliances indoors results in a timedependent inflammatory response in the lung (Sandstrom et al. 1991).

Epidemiological studies have consistently reported associations between particulate air pollution, especially PM $<10 \mu \mathrm{m}$ in aerodynamic diameter, and adverse health effects, increasing morbidity and mortality (Samet et al. 2000). However, it is by no means clear how exposure to $\mathrm{PM}$, typically as low as $30 \mu \mathrm{g} / \mathrm{m}^{3}$, can produce these health effects and which components of PM mediate them. Although epidemiological evidence suggests that it is the fine (PM of $0 \cdot 1-2 \cdot 5 \mu \mathrm{m}$ in aerodynamic diameter) or ultrafine (PM of $<0.1 \mu \mathrm{m}$ in aerodynamic diameter) fraction that contains the toxic components, there is no general agreement. Moreover, the wide spectrum of disease end points (from cardiovascular death to an asthma attack) suggests that more than one component may be driving the health effects.

\section{Air pollution and oxidative stress}

The three traffic-related pollutants causing most concern include the primary pollutants $\mathrm{NO}_{2}$ and $\mathrm{PM}$ of $<10 \mu \mathrm{m}$, and the secondary pollutant $\mathrm{O}_{3}$. All these pollutants are toxic to the lung, and in ambient air they usually coexist in varying combinations. Although the properties of these pollutants vary markedly, they all have one common feature, which is that they can cause oxidative stress. Oxidative stress is a relatively new term in biology that was introduced by Sies (1991) to describe non-lung phenomena. However, the concept is a global one and can relate to events occurring in any tissue. Oxidative stress is a situation in which the prooxidant-antioxidant balance is disturbed. This imbalance can occur when the generation of oxidant molecules, or free radicals, exceeds the available antioxidant defences (for an overview of the distribution of intracellular and extracellular antioxidant defences in the lung, see Fig. 1). The damage arising from aberrant free radical activity is often loosely referred to as oxidative stress, and it is characterised by the presence of increased 


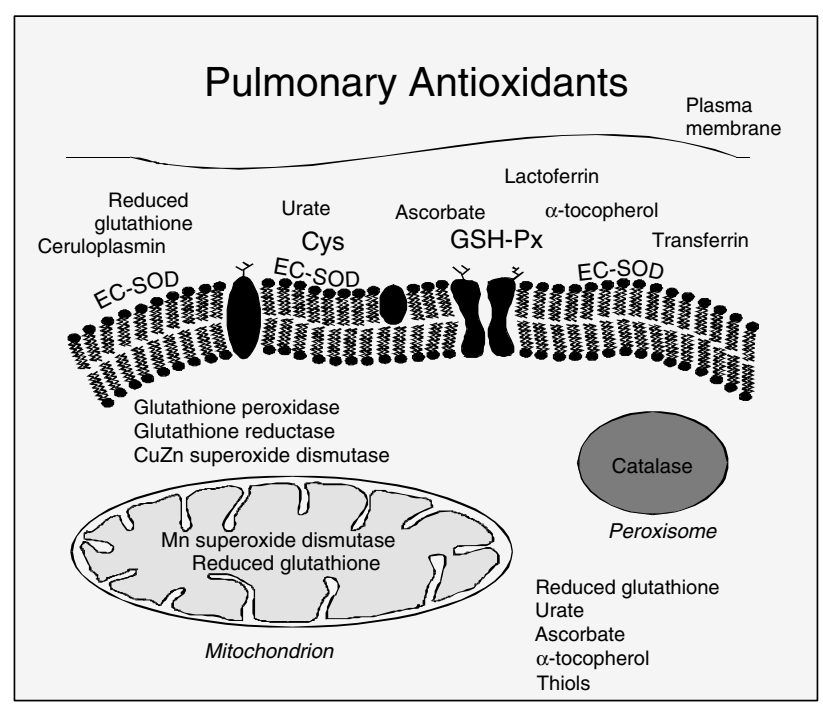

Fig. 1. Distribution of antioxidants in the extracellular and intracellular compartments of the lung. Cys, cysteine; GSH-Px, glutathione peroxidase; EC-SOD, extracellular superoxide dismutase.

cellular concentrations of oxidised lipids, proteins and nucleic acids. Many of these oxidation products become ineffective; for example, many enzymes become inactivated following oxidation. Of the three ambient air pollutants of primary concern: $\mathrm{NO}_{2}$ is a free radical, as it contains unpaired electrons in its outer electron orbital; $\mathrm{O}_{3}$, although not a free radical, is a powerful oxidant, second only to $\mathrm{Fl}$ in redox potential; much of the PM carries on its surface metal and organic contaminants that are capable of generating free radicals (Kelly, 2003).

On entering the lung, ambient pollutants do not come into direct contact with respiratory epithelial cells, but rather their first contact is with the fluid layer that covers the respiratory epithelium, the respiratory-tract lining fluid (RTLF; Fig. 2). Thus, the responses observed following exposure to ambient pollutants are thought to be mediated through oxidation reactions occurring within this fluid air-lung interface (Pryor, 1994). In the case of $\mathrm{O}_{3}$, and to a lesser extent $\mathrm{NO}_{2}$, because of its low solubility and high reactivity (Medinsky \& Bond, 2001), these reactions appear to be confined to the RTLF. As a result, little $\mathrm{O}_{3}$ is thought to react directly with the underlying cells. Instead, its toxicity is transmitted to the respiratory epithelium by secondary oxidation products formed by the direct ozonisation of RTLF lipids (Pryor et al. 1995). These species trigger the underlying cells to elaborate inflammatory signals (Kafoury et al. 1999), resulting in airway neutrophilia with ensuing tissue injury. Particulate pollution can, in contrast, cross the RTLF layer; however, it is likely that in making the transition the oxidative nature of the particle surface will be changed as a result of reactions with components of the RTLF (Kelly, 2003).

\section{Antioxidants and normal lung function}

Opposing the formation of cytotoxic species in the RTLF is a network of antioxidants: ascorbate (van der Vliet et al.
1999), urate (Peden et al. 1990), reduced glutathione (Cantin et al. 1987), $\alpha$-tocopherol (Mudway et al. 2001), extracellular superoxide dismutase (Mudway et al. 2001) and glutathione peroxidase (Avissar et al. 1996). All these antioxidants are free-radical scavengers, but many (ascorbate and urate) also function as sacrificial targets for $\mathrm{O}_{3}$, reacting rapidly with this oxidant to limit its interaction with RTLF lipids and proteins (Pryor et al. 1995). It has been proposed that the composition and quantity of antioxidants within the RTLF might therefore represent an important determinant of an individual's responsiveness to $\mathrm{O}_{3}$ (Kelly et al. 1995). Indeed, there is evidence (discussed later, see p. 582) that increased antioxidant intake may protect against the effects of air pollution.

Both the extracellular compartment (RTLF) and the intracellular components of the lung are well endowed with antioxidant defences (Fig. 1). Whilst there is evidence to suggest that good lung function is associated with diets rich in fruits and vegetables (Britton et al. 1995), there is little data linking basal pulmonary or blood antioxidant levels to an individual's responsiveness to oxidant gases under controlled conditions (Blomberg et al. 1999; Mudway et al. 2001). It is, however, conceivable that boosting the plasma concentrations of these antioxidants above the normal range could have a protective effect, if this strategy results in augmented RTLF antioxidant concentrations.

Interest in dietary antioxidants first arose in the area of lung disease in the 1980s, with the suggestion from retrospective observational studies that individuals with low intakes of dietary antioxidants have decreased lung function. Studies by Cohen and colleagues (Tockman et al. 1986; Morabia et al. 1989) indicated that dietary retinol levels are an important predictor of lung function, in that individuals with higher retinol intakes tend to have better lung function. Schwartz \& Weiss (1990), reporting the findings of the National Health and Nutrition Examination Survey study, observed that the dietary intake of vitamin C is positively associated with a measure of lung function (forced expiratory volume in $1 \mathrm{~s} ; \mathrm{FEV}_{1}$ ). Strachan et al. (1991) found that smokers with high intakes of fresh fruit and fruit juice have a higher $\mathrm{FEV}_{1}$ than those with a low intake of these foods. In the Zutphen study (Miedema et al. 1993) it was shown that fruit intake is inversely related to the incidence of chronic non-specific lung disease, but there is no association with the estimated intakes of several antioxidants, including $\beta$-carotene, vitamin $\mathrm{C}$ and Se. In the MORGEN study (the monitoring project on risk factors and health in The Netherlands) it was found that a high intake of vitamin $\mathrm{C}$ and $\beta$-carotene, but not vitamin $\mathrm{E}$, is associated with a higher $\mathrm{FEV}_{1}$ and forced vital capacity (total volume expired; FVC) than a low intake of these antioxidants, suggesting that these nutrients do have a protective effect on lung function (Grievink et al. 1998).

In addition to these epidemiological studies, there are a number of cross-sectional studies in which associations have been made between blood concentrations of dietary antioxidants and lung function and/or respiratory symptoms. Taylor et al. (1986) have reported that patients with chronic obstructive pulmonary disease who have an abnormal $\mathrm{FEV}_{1}: \mathrm{FVC}$ have decreased plasma antioxidant levels. The findings of the National Health and Nutrition 


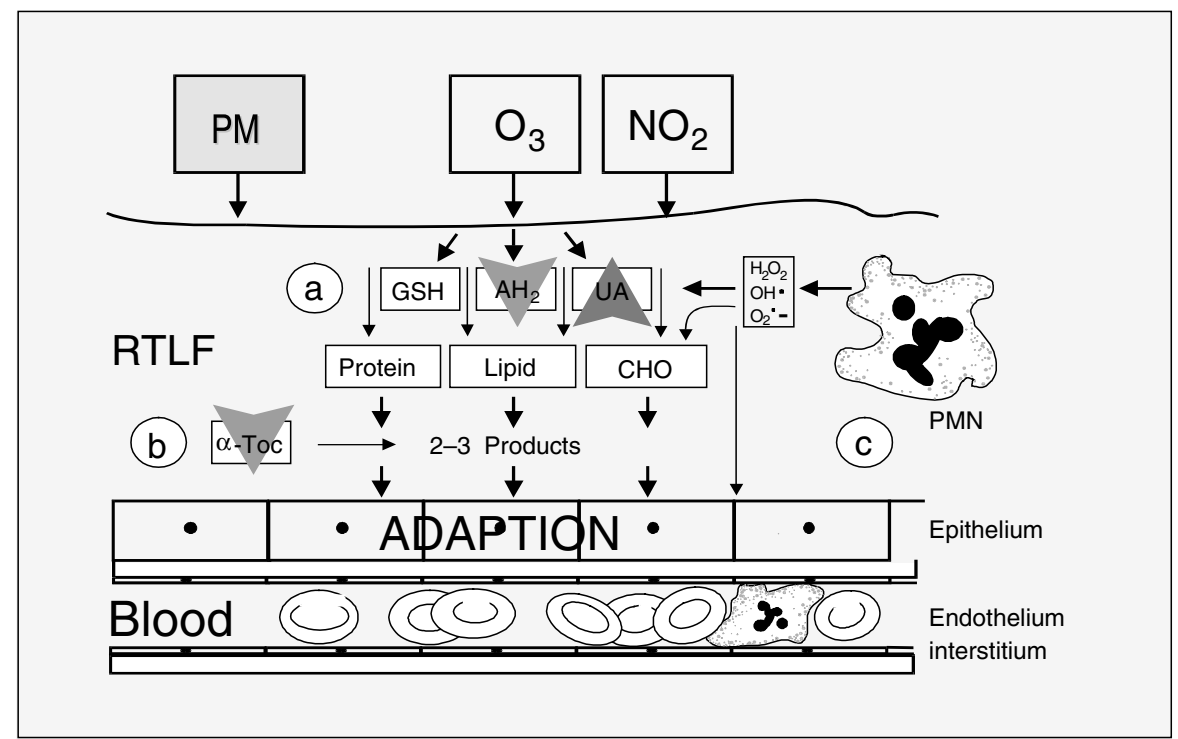

Fig. 2. Schematic model of how oxidant air pollutants interact with the lung. RTLF, respiratory tract lining fluid; GSH, reduced glutathione; $\mathrm{AH}_{2}$, ascorbic acid; UA, uric acid; $\alpha$ Toc, $\alpha$-tocopherol; PMN, polymorphonucleoctyes; $\mathrm{CHO}$, carbohydrate. (a), First interactions are between the pollutants and the protecting hyrdrophilic antioxidants; (b), subsequent reactions probably occur with antioxidants on the respiratory epithelium; (c), oxidative reactions lead to the generation of chemotactic signals, which lead to the influx of activated polymorphonucleoctyes onto the lung surface.

Examination Survey II study (Schwartz \& Weiss, 1994) suggest that both bronchitis and wheeze are negatively associated with serum vitamin C levels. Ness et al. (1996) have reported that plasma vitamin $\mathrm{C}$ concentration correlate with both $\mathrm{FEV}_{1}$ and $\mathrm{FVC}$ in men but not women. More recently, Mudway et al. (2000) have shown that $\mathrm{FEV}_{1}$ is not influenced by vitamin $\mathrm{C}$ supplementation in healthy vitamin C-replete subjects.

As outlined earlier, a growing body of evidence links the intake of vitamins and provitamin $\beta$-carotene with lung function; i.e. a high intake of these dietary components is associated with higher $\mathrm{FEV}_{1}$ and FVC than low intakes, presumably as a result of improved antioxidant reserves to deal with the inevitable increases in reactive oxygen species. This scenario has been demonstrated in patients with cystic fibrosis who, because of decreased production of pancreatic juices, are unable to efficiently breakdown and absorb fat-soluble vitamin antioxidants such as vitamins E and A (Bye et al. 1985; Homnick et al. 1993). This problem, along with recurrent airway infections and increased neutrophil activity, means that patients with cystic fibrosis endure regular bouts of increased oxidative stress (Brown \& Kelly, 1994). Moreover, as both lung function and antioxidant status decline with age in patients with cystic fibrosis (Brown et al. 1996), it is possible that these two events are linked, although no long-term prospective studies have yet addressed this interesting possibility. Encouragingly, short-term intervention studies have shown that $\beta$-carotene supplementation reduces circulating markers of lipid peroxidation in patients with cystic fibrosis (Winklhofer-Roob et al. 1995; Lepage et al. 1996). More recently, Wood et al. (2002) have demonstrated that high-dose antioxidant supplementation (/d;200 mg vitamin $\mathrm{E}, 300 \mathrm{mg}$ vitamin $\mathrm{C}, 25 \mathrm{mg} \beta$-carotene, $90 \mu \mathrm{g} \mathrm{Se}$, $500 \mu \mathrm{g}$ vitamin A) improves the antioxidant status of patients with cystic fibrosis, which appears to be linked with an improvement in lung function.

\section{Air pollution and antioxidant intake}

In support of the proposed benefit from increased antioxidant intake, recent field studies have demonstrated that increased intakes of nutritional antioxidants can reduce the magnitude of lung function decrements in subjects exposed to high $\mathrm{O}_{3}$ doses both occupationally (shoe cleaners in Mexico City; Romieu et al. 1998) and recreationally (Dutch cyclists; Grievink et al. 1999). In these studies it was observed that prolonged periods of supplementation (75 mg vitamin $\mathrm{E}, 650 \mathrm{mg}$ vitamin $\mathrm{C}, 15 \mathrm{mg} \beta$-carotene daily for 1.5 months in the Mexico City study; $100 \mathrm{mg}$ vitamin E, $500 \mathrm{mg}$ vitamin $\mathrm{C}$ daily for 15 weeks in the Dutch cyclist study) are associated with protection against average $\mathrm{O}_{3}$ backgrounds of $67.3 \mu \mathrm{g} / \mathrm{m}^{3}$ and $38.5 \mu \mathrm{g} / \mathrm{m}^{3}$ respectively. Notably, major $\mathrm{O}_{3}$ episodes were only recorded in the Mexico City study, with numerous hourly episodes $>110 \mu \mathrm{g} / \mathrm{m}^{3}$.

Corroboration for these findings has been provided in a number of controlled chamber studies. Chatham et al. (1987) have reported protection against $\mathrm{O}_{3}$-induced $\left(600 \mu \mathrm{g} / \mathrm{m}^{3}\right.$ for $2 \mathrm{~h}$, with intermittent exercise) decrements in FVC in subjects receiving a daily supplement of $528 \mathrm{mg}$ vitamin $\mathrm{E}$ for $14 \mathrm{~d}$ with a single $1 \mathrm{~g}$ vitamin $\mathrm{C}$ dose taken immediately before the $\mathrm{O}_{3}$ challenge. Notably, in this study no protection was observed with vitamin $\mathrm{C}$ alone, and no protection against $\mathrm{FEV}_{1}$, forced expiratory flow (25th-75th percentile), or specific airway conductance 
decrements was observed. A recent (double-blinded) study has examined a fuller range of response end points in two groups of sixteen subjects exposed to $\mathrm{O}_{3}$ at $800 \mu \mathrm{g} / \mathrm{m}^{3}$ for $2 \mathrm{~h}$ while exercising at a ventilation rate of $201 / \mathrm{min}$ per $\mathrm{m}^{2}$ following placebo and vitamin supplementation (250 mg vitamin C, $33 \mathrm{mg}$ vitamin $\mathrm{E}$ and a $370 \mathrm{~g}(12 \mathrm{oz})$ vegetable cocktail rich in carotenoids daily for $14 \mathrm{~d}$; Samet et al. 2001). In this study a small yet significant blunting of the $\mathrm{O}_{3}$-induced decrement in $\operatorname{FEV}_{1}(P=0.05)$ was observed in the supplemented group with a similar trend $(P=0 \cdot 06)$ observed in the FVC response. No protection against $\mathrm{O}_{3}$-induced airway inflammation was reported. In this study subjects were initially placed on a restrictedantioxidant diet for $7 \mathrm{~d}$ before entering the placebo or vitamin predosing period, such that their initial vitamin $\mathrm{C}$, vitamin $\mathrm{E}$, and $\beta$-carotenoid concentrations were low (group means of $34.2,13.3$ and $1.4 \mu \mathrm{mol} / 1$ respectively). In field studies in which protection has been observed basal blood antioxidant levels, when measured, have been at the upper end of the normal range (Grievink et al. 1998, 1999; Romieu et al. 1998). Whilst these studies have examined responses in healthy subjects, a recent study by Trenga et al. (2001) has addressed whether vitamin supplementation $(500 \mathrm{mg}$ vitamin $\mathrm{C}$ and $264 \mathrm{mg}$ vitamin $\mathrm{E}$ daily for 4 weeks) would protect asthmatics against $\mathrm{O}_{3^{-}}$ induced $\left(120 \mu \mathrm{g} / \mathrm{m}^{3}\right.$ for $45 \mathrm{~min}$, with mild exercise) lung function decrements and following subsequent provocation with $\mathrm{SO}_{2}\left(100\right.$ and $\left.250 \mu \mathrm{g} / \mathrm{m}^{3}\right)$. No difference between the pre- and post- $\mathrm{O}_{3}$ lung function decrements (FVC, $\mathrm{FEV}_{1}$, forced expiratory flow (25th-75th percentile) and positive expiratory flow) was observed between the supplement and placebo groups. Similarly, no difference was observed in the lung function decrement after $\mathrm{SO}_{2}$. Indeed, overall responses actually appeared to be larger in the vitaminreceiving group. In each of these studies statistical power is limited both by small group sizes and the fact that subjects do not act as their own controls. Further, although chamber studies have reported protection against $\mathrm{O}_{3}$ with vitamin supplementation the end points in which protection was seen are not consistent, and the magnitude of the protective effect is small.

Although it has recently been hypothesised that low antioxidant intake may result in accelerated loss of lung function with ageing (Kelly, 2003), few studies have explored whether there is a relationship between antioxidant intake and lung function in childhood. Cook et al. (1997) have reported a positive association between $\mathrm{FEV}_{1}$ and the frequency of fresh fruit consumption and a weak association with green vegetable and salad consumption. As they found no association between $\mathrm{FEV}_{1}$ and serum vitamin $\mathrm{C}$ concentration, they concluded that other micronutrient antioxidants derived from these foods are more important than ascorbic acid. More recently, Gilliland et al. (2003) have reported that low intakes of antioxidant vitamins are associated with deficits in pulmonary function in both boys and girls participating in the Children's Health Study in California. Importantly, the deficits amongst boys with asthma are large enough to be clinically significant. Gilliland et al. (2003) have suggested that low antioxidant intake during childhood may contribute to the risk of developing obstructive lung disease during adulthood, as well as increased morbidity and mortality associated with low $\mathrm{FEV}_{1}$.

In conclusion, the air breathed contains many products of human activity that pose important challenges to the health of the population. Atmospheric oxidative pollutants in particular pose an important challenge to the maintenance of normal lung function. Gaseous air pollutants, such as $\mathrm{O}_{3}$, are thought to play a role in the causation and aggravation of asthma and allergic responses that are increasingly prevalent in children. Although still under active discussion, many investigators now believe that oxidative stress plays a central role in the impact of air pollutants such as $\mathrm{O}_{3}$ and PM. Oxidative stress, by definition, is an imbalance between oxidants and antioxidants. As many antioxidants are derived from the food eaten, increased attention is being paid to the quality of the diet, and how this strategy may help protect the population from an oxidising environment.

\section{Acknowledgements}

The work undertaken in the author's laboratory has been supported by the Food Standards Agency, the Medical Research Council and the Wellcome Trust.

\section{References}

Abbey DE, Nishino N, McDonnell WF, Burchette RJ, Knutsen SF, Lawrence Beeson W \& Yang JX (1999) Long-term inhalable particles and other air pollutants related to mortality in nonsmokers. American Journal of Respiratory and Critical Care Medicine 159, 373-382.

Aris RM, Christian D, Hearne PQ, Kerr K, Finkbeiner WE \& Balmes JR (1993) Ozone-induced airway inflammation in human subjects as determined by airway lavage and biopsy. American Review of Respiratory Disease 148, 1363-1372.

Avissar N, Finkelstein JN, Horowitz S, Willey JC, Coy E, Frampton MW, Watkins RH, Khullar P, Xu YL \& Cohen HJ (1996) Extracellular glutathione peroxidase in human lung epithelial lining fluid and in lung cells. American Journal of Physiology 270, L173-L182.

Blomberg A, Mudway IS, Nordenhall C, Hedenstrom H, Kelly FJ, Frew AJ, Holgate ST \& Sandstrom T (1999) Ozoneinduced lung function decrements do not correlate with early airway inflammatory or antioxidant responses. European Respiratory Journal 13, 1418-1428.

Britton JR, Pavord ID, Richards KA, Knox AJ, Wisniewski AF, Lewis SA, Tattersfield AE \& Weiss ST (1995) Dietary antioxidant vitamin intake and lung function in the general population. American Journal of Respiratory and Critical Care Medicine 151, 1383-1387.

Brown RK \& Kelly FJ (1994) Role of free radicals in the pathogenesis of cystic fibrosis. Thorax 49, 738-742.

Brown RK, Wyatt H, Price JF \& Kelly FJ (1996) Pulmonary dysfunction in cystic fibrosis is associated with oxidative stress. European Respiratory Journal 9, 334-339.

Bye AM, Muller DPR, Wilson J, Wright VM \& Mearns MB (1985) Symptomatic vitamin E deficiency in cystic fibrosis. Archives of Disease in Childhood 60, 162-164.

Cantin AM, North SL, Hubbard RC \& Crystal RG (1987) Normal alveolar epithelial lining fluid contains high levels of glutathione. Journal of Applied Physiology 63, 152-157.

Chatham MD, Eppler JH Jr, Sauder LR, Green D \& Kulle TJ (1987) Evaluation of the effects of vitamin C on ozone-induced 
bronchoconstriction in normal subjects. Annals of the New York Academy of Sciences 498, 269-279.

Cook DG, Carey IM, Whincup PH, Papacosta O, Chirico S, Bruckdorfer KR \& Walker M (1997) Effect of fresh fruit consumption on lung function and wheeze in children. Thorax 52, 628-633.

Devlin RB, McDonnell WF, Mann R, Becker S, House DE, Schreinemachers D \& Koren HS (1991) Exposure of humans to ambient levels of ozone for $6 \cdot 6$ hours causes cellular and biochemical changes in the lung. American Journal of Respiratory Cell and Molecular Biology 4, 72-81.

Dockery DW (2001) Epidemiologic evidence of cardiovascular effects of particulate air pollution. Environmental Health Perspectives 109, Suppl. 4, 483-486.

Dockery DW, Pope CA, Xu X, Spengler JD, Ware JH, Fay ME, Ferris BG, Speizer FE, Pope AC 3rd, Ferris BG Jr \& Pope AC (1993) An association between air pollution and mortality in six US cities. New England Journal of Medicine 329, $1753-1759$.

Gilliland FD, Berhane KT, Yu-Fen Li, Gauderman J, McConnell R \& Peters J (2003) Children's lung function and antioxidant vitamin, fruit juice and vegetable intake. American Journal of Epidimology 158, 576-584.

Grievink L, Jansen SM, van't Veer P \& Brunekreef B (1998) Acute effects of ozone on pulmonary function of cyclists receiving antioxidant supplements. Occupational and Environmental Medicine 55, 13-17.

Grievink L, Smit HA, Ocké MC, Van't Veer P \& Kromhout D (1998) Dietary intake of antioxidant (pro)-vitamins, respiratory symptoms and pulmonary function: The MORGEN study. Thorax 53, 166-171.

Grievink L, Zijlstra AG, Ke X \& Brunekreef B (1999) Doubleblind intervention trial on modulation of ozone effects on pulmonary function by antioxidant supplements. American Journal of Epidemiology 149, 306-314.

Homnick DN, Cox JH, Deloof MJ \& Ringer TV (1993) Carotenoid levels in normal children and in children with cystic fibrosis. Journal of Pediatrics 122, 703-707.

Kafoury RM, Pryor WA, Squadrito GL, Salgo MG, Zou X \& Friedman M (1999) Induction of inflammatory mediators in human airway epithelial cells by lipid ozonation products. American Journal of Respiratory and Critical Care Medicine 160, 1934-1942.

Kelly FJ (2003) Oxidative stress; its role in air pollution and adverse health effects. Occupational and Environmental Medicine 60, 612-616.

Kelly FJ, Mudway I, Krishna MT \& Holgate ST (1995) The free radical basis of air pollution: focus on ozone. Respiratory Medicine 89, 647-656.

Koren HS, Devlin RB, Graham DE, Mann R, McGee MP, Horstman DH, et al. (1989) Ozone-induced inflammation in the lower airways of human subjects. American Review of Respiratory Disease 139, 407-415.

Lepage G, Champagne J, Ronco N, Lamarre A, Osberg I, Sokol R \& Roy CC (1996) Supplementation with carotenoids corrects increased lipid peroxidation in children with cystic fibrosis. American Journal of Clinical Nutrition 64, 87-93.

Medinsky MA \& Bond JA (2001) Sites and mechanisms for uptake of gases and vapors in the respiratory tract. Toxicology 160, 165-172.

Miedema I, Feskens EJM, Heederik D \& Kromhout D (1993) Dietary determinations of long term incidence of chronic nonspecific lung disease. The Zutphen study. American Journal of Epidemiology 138, 37-45.

Morabia AA, Soreenson A, Kumanyika SK, Abbey H, Cohen BH \& Chee E (1989) Vitamin A, cigarette smoking, and airway obstruction. American Review of Respiratory Disease 140, $1312-1316$

Mudway I, Blomberg A, Helleday R, Frew A, Sandstrom T \& Kelly FJ (2000) Supplementation with vitamin C does not influence lung function in healthy subjects. European Respiratory Journal 16, 116s.

Mudway IS \& Kelly FJ (2000) Ozone and the lung: a sensitive issue. Molecular Aspects of Medicine 21, 1-48.

Mudway IS, Stenfors N, Blomberg A, Helleday R, Dunster C, Marklund SL, Frew AJ, Sandstrom T \& Kelly FJ (2001) Differences in basal airway antioxidant concentrations are not predictive of individual responsiveness to ozone: a comparison of healthy and mild asthmatic subjects. Free Radical Biology and Medicine 31, 962-974.

Ness AR, Khaw KT, Bingham S \& Day NE (1996) Vitamin C status and respiratory function. European Journal of Clinical Nutrition 50, 573-579.

Peden DB, Hohman R, Brown ME, Mason RT, Berkebile C, Fales HM \& Kaliner MA (1990) Uric acid is a major antioxidant in human nasal airway secretions. Proceedings of the National Academy of Sciences USA 87, 7638-7642.

Pope CA, Burnett RT, Thun MJ, Calle EE, Krewski D, Ito K \& Thurston GD (2002) Lung cancer, cardiopulmonary mortality, and long-term exposure to fine particulate air pollution. Journal of the American Medical Association 287, $1132-1141$

Pope CA, Thun MJ, Namboodiri MM, Dockery DW, Evans JS, Speizer FE, Heath CW, Pope CA 3rd \& Heath CW Jr (1995) Particulate air pollution as a predictor of mortality in a prospective study of US adults. American Journal of Respiratory and Critical Care Medicine 151, 669-674.

Pryor WA (1994) Mechanisms of radical formation from reactions of ozone with target molecules in the lung. Free Radical Biology and Medicine 17, 451-465.

Pryor WA, Squadrito GL \& Friedman M (1995) A new mechanism for the toxicity of ozone. Toxicology Letters 82-3, 287-293.

Romieu I, Meneses F, Ramirez M, Ruiz S, Perez Padilla R, Sienra JJ, Gerber M, Grievink L, Dekker R, Walda I \& Brunekreef B (1998) Antioxidant supplementation and respiratory functions among workers exposed to high levels of ozone. American Journal of Respiratory and Critical Care Medicine 158, 226-232.

Samet JM, Dominici F, Curriero FC, Coursac I \& Zeger SL (2000) Fine particulate air pollution and mortality in 20 U.S. cities, 1987-1994. New England Journal of Medicine 343, $1742-1749$.

Samet JM, Hatch GE, Horstman D, Steck-Scott S, Arab L, Bromberg PA, Levine M, McDonnell WF \& Devlin RB (2001) Effect of antioxidant supplementation on ozone-induced lung injury in human subjects. American Journal of Respiratory and Critical Care Medicine 164, 819-825.

Sandstrom T, Stjernberg N, Eklund A, Ledin MC, Bjermer L, Kolmodin-Hedman B, Lindstrom K, Rosenhall L \& Angstrom $\mathrm{T}$ (1991) Inflammatory cell response in bronchoalveolar lavage fluid after nitrogen dioxide exposure of healthy subjects: a dose-response study. European Respiratory Journal 3, 332-339.

Schelegle ES, Siefkin AD \& McDonald RJ (1991) Time course of ozone-induced neutrophilia in normal humans. American Review of Respiratory Disease 143, 1353-1358.

Schwartz J \& Weiss ST (1990) Dietary factors and their relation to respiratory symptoms. The second National Health and Nutrition Examination Survey. American Journal of Epidemiology 132, 67-76.

Schwartz J \& Weiss ST (1994) Relationship between dietary vitamin $\mathrm{C}$ intake and pulmonary function in the First National 
Health and Nutrition Examination Survey (NHANES I). American Journal of Clinical Nutrition 59, 110-114.

Sies H (1991) Oxidative stress II. Oxidants and Antioxidants, pp. 1-23. London. Academic Press.

Strachan DP, Cox BD, Erzinclioglu SW, Walters E \& Whichelow MJ (1991) Ventilatory function and winter fresh fruit consumption in a random sample of British adults. Thorax 46, 624-629.

Taylor JC, Madison R \& Kosinka D (1986) Is antioxidant deficiency related to chronic obstructive disease. American Review of Respiratory Disease 134, 285-289.

Tockman MS, Khoury MJ \& Cohen BH (1986) Milk drinking and possible protection of the respiratory epithelium. Journal of Chronic Diseases 39, 207-209.

Trenga CA, Koenig JQ \& Williams PV (2001) Dietary antioxidants and ozone-induced bronchial hyperresponsiveness in adults with asthma. Archives of Environmental Health 56, 242-249.
UK Parliament (1956) Clean Air Act 1956. London: H. M. Stationery Office.

van der Vliet A, O'Neill CA, Cross CE, Koostra JM, Volz WG, Halliwell B \& Louie S (1999) Determination of lowmolecular-mass antioxidant concentrations in human respiratory tract lining fluids. American Journal of Physiology 276, L289-L296.

Winklhofer-Roob BM, Puhl H, Khoschsorur G, van't Hof MA, Esterbauer H \& Shmerling DH (1995) Enhanced resistance to oxidation low density lipoproteins and decreased lipid peroxide formation during beta-carotene supplementation in cystic fibrosis. Free Radical Biology and Medicine 18, 849-859.

Wood LG, Fitzgerald DA, Lee AK \& Garg ML (2002) Improved antioxidant and fatty acid status of patients with cystic fibrosis after antioxidant supplementation is linked to improved lung function. American Journal of Clinical Nutrition 77, 150-159. 
https://doi.org/10.1079/PNS2004388 Published online by Cambridge University Press 